\title{
Phosphorus Fractions and Phosphorus Adsorption Characteristics of Soils from the Water-Level Fluctuating Zone of Nansi Lake, China
}

\author{
Yanhao Zhang ${ }^{1}$, Lilong Huang ${ }^{1}$, Zhibin Zhang, ${ }^{1,2 *}$, \\ Leilei Wei ${ }^{3}$, Cuizhen Sun ${ }^{1}$, Dongchen Chen ${ }^{1}$, Weimin Wu ${ }^{2}$ \\ ${ }^{1}$ College of Municipal and Environmental Engineering, Shandong Jianzhu University, \\ Jinan 250101, P.R.China \\ ${ }^{2}$ Center for Sustainable Development \& Global Competitiveness, Stanford University, \\ Stanford, CA 94305, USA \\ ${ }^{3}$ Everbright Water Limited Company, \\ Jinan 250014, P.R.China
}

Received: 11 June 2015

Accepted: 10 December 2015

\begin{abstract}
Nansi Lake, a typical shallow and macrophyte-dominated lake in south Shandong Province, China, has a total surface area of $1,266 \mathrm{~km}^{2}$ and is the largest and most important freshwater reservoir in northern China for the eastern route of the South-North Water Diversion (SNWD) project, in which the water in Yangtze River will be transported more than 1,100 km from Yangzhou to Tianjin and Beijing. A water-level fluctuating zone (WLFZ) near Nansi Lake will be formed when the SNWD project begins to transport water flowing through the lake. Phosphorus fractions and adsorption-release characterization for soil samples from four typical lands (reed, wood, maize, and soybean) were conducted to investigate soil phosphorus stability. In addition, a soil submerged experiment was performed to simulate phosphorus release under submerged conditions. Phosphorus adsorption-desorption equilibrium concentrations $\left(\mathrm{C}_{\mathrm{EPC}}\right)$ of four lands were 0.006 , $0.089,0.110$, and $0.287 \mathrm{mg} \mathrm{L}^{-1}$, respectively, which means that maize, soybean, and woodland had higher potentials than reed land for phosphorus releasing to the overlaying water. Submerged experiment results showed that the quantities of phosphorus released from reed, wood, maize, and soybean soils were -0.14 , $0.06,0.12$, and $0.97 \mathrm{mg} \mathrm{kg}^{-1}$, respectively. Soils in the reed land adsorbed phosphorus from overlying water, but the other soils released phosphorus into the water. Thus, in order to decrease the phosphorus releasing quantity from the wood, soybean, and maize land under the conditions of submerged lands at water diversion time, the land uses of wood, soybean, and maize should be switched to land for planting reed.
\end{abstract}

Keywords: water-level fluctuating zone (WLFZ), soil, phosphorus release, phosphorus adsorption, Nansi Lake

*e-mail: zhazhb@163.com 


\section{Introduction}

A water-level fluctuating zone (WLFZ) is a special zone where the area of submerged soils changes seasonally with the seasonal water level fluctuation of a reservoir or lake. It is the most extraordinary and fragile zone in aquatic and land ecosystems [1-4]. Riis and Hawes reported that water level fluctuations influenced vegetation diversity [5]. Lawniczak et al. found that the reduction of water level resulted in a negative effect on biomass production and nutrient concentrations [6]. Fluctuating water levels increase the area of shoreline vegetation, and the diversity of vegetation types and plant species. Any stabilization of water levels would likely reduce marsh area, vegetation diversity, and plant species diversity [2,79]. Sasikala et al. reported that the water level fluctuation caused a considerable reduction in radial oxygen loss and root porosity, and produced a significant improvement in total nitrogen (TN) and $\mathrm{NH}_{4}^{+}-\mathrm{N}$ removal [10]. Lawniczak et al. evaluated the changes in soil $\mathrm{P}$ speciation and availability with time following applications of grain-fed cattle manure or monoammonium phosphate. They found that fluctuations in total bioactive soil $\mathrm{P}$ were two to four times greater than aboveground biomass $\mathrm{P}$, highlighting the importance of accounting for seasonal dynamics in assessing offsite $\mathrm{P}$ transport risks [11]. However, research on the phosphorus fraction releasing from soils in WLFZ is rare.

To solve the water resource shortage in northern China, the South-to-North Water Diversion (SNWD) project has been conducted to transfer the water in Yangtze River to the North China, and the conduit canals for the project have three routes (named West, Middle, and East). For the East route, water will be diverted from the Yangtze to Hebei and Shandong provinces during the autumn, winter, and spring seasons (summer excluded). After the project is completed, a $0.5 \mathrm{~m}$ high WLFZ will be formed at Nansi Lake. The soils around Nansi or situated in the WLFZ will be submerged during the period of water-diverting periods and then emerge above water level again in summer. According to the Chinese governmental regulation titled "Water Pollution Prevention Planning of the SNWD (East route) of Shandong Section," the phosphorus content of the overlying water in Nansi Lake should be controlled below $0.05 \mathrm{mg} \mathrm{L}^{-1}$ [12]. Currently, the potential WLFZ has been farmland for maize, soybean, and wheat production for a long time. During recent years, the dosage of phosphorus fertilizer to farmland keeps increasing in order to enhance the yield of crops, and often exceeds phosphorus uptake by crops. The phosphorus fractions and quantities in soils were inconstant in the different conditions [13-15]. Numerous studies support the idea that phosphorus-based fertilization had increased the potential for phosphorus release from soils [16-20]. The resin-extractable $\mathrm{P}$ and $\mathrm{NaHCO}_{3}$-extractable inorganic $\mathrm{P}$ and $\mathrm{NaOH}$-extractable organic $\mathrm{P}$ significantly increased under $\mathrm{P}$ fertilization in cultivated soils during two years [19]. However, Kai Y. et al. reported that $\mathrm{N}$ addition decreased soil inorganic $\mathrm{P}$ availability, microbial biomass $\mathrm{P}$, and acid phosphatase activity in the larch plantation. Soil inorganic $P$ availability decreased after $\mathrm{N}$ addition due to the changes in both microbial properties and plant uptake [21]. The $\mathrm{P}$ in the
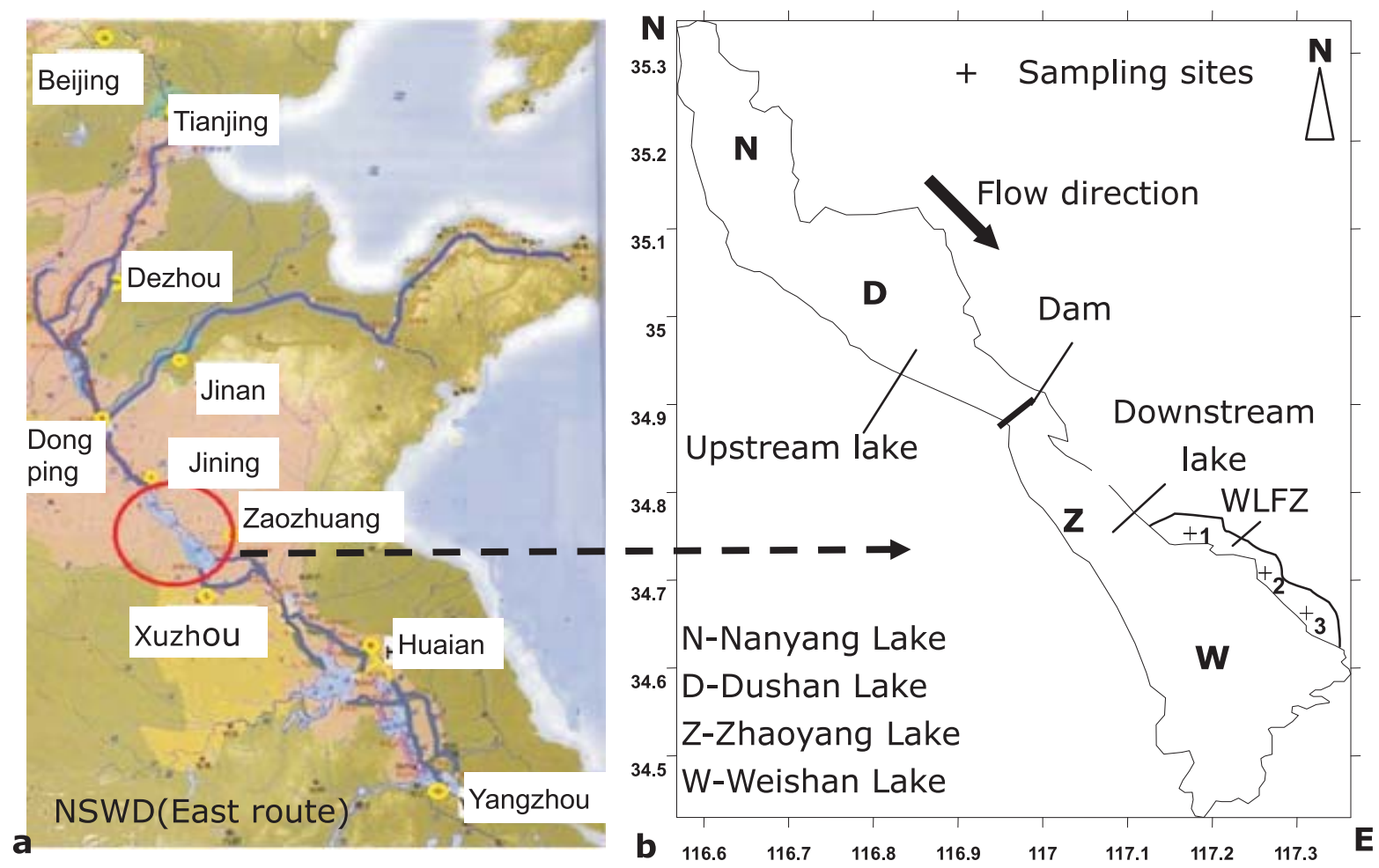

Fig. 1. Geographic map of the South-to-North Water Diversion (East route) project and sediment sampling sites at the water-level fluctuating zone (WLFZ) in Nansi Lake. 
albic bleached luvisol meadow soil was mainly associated with $\mathrm{Fe}$ oxides and organic matter, and Fe-P supports the majority of available $P$ [22]. Therefore, it is necessary to investigate the $\mathrm{P}$ fractions in WLFZ. When the soil in WLFZ is submerged, the phosphorus released from soil into the overlying water would represent greater potential for contamination of surface and subsurface waters $[8,23$, 24].

Study on soil $\mathrm{P}$ fraction in WLFZ is an important aspect in probing the mechanisms of soil $\mathrm{P}$ accumulation in farmland and mitigating its losing risk to the environment. The objective of this research is to investigate phosphorus fractions and phosphorus release performance in WLFZ, and to evaluate the potential effect of various land usage on lake water quality in the future.

\section{Materials and Methods}

\section{Lake Site and Soil Sampling}

Nansi Lake $\left(34^{\circ} 27^{\prime}-35^{\circ} 20^{\prime} \mathrm{N}, 116^{\circ} 34^{\prime}-117^{\circ} 21^{\prime} \mathrm{E}\right)$ is situated southwest of Shandong Province and consists of four consecutive lakes, i.e., Nanyang (N), Dushan (D), Zhaoyang $(\mathrm{Z})$, and Weishan $(\mathrm{W})$. The total surface area is $1,266 \mathrm{~km}^{2}$ with an average depth of $1.46 \mathrm{~m}$. It serves as a buffer lake of the East route (Fig. 1).

The soil samples were taken from three sites, i.e., site 1 $\left(34^{\circ} 42^{\prime} \mathrm{N}, 117^{\circ} 11^{\prime} \mathrm{E}\right)$, site $2\left(34^{\circ} 40^{\prime} \mathrm{N}, 117^{\circ} 16^{\prime} \mathrm{E}\right)$, and site 3 $\left(34^{\circ} 37^{\prime} \mathrm{N}, 117^{\circ} 20^{\prime} \mathrm{E}\right)$ in the WLFZ (Fig. 1). The farm lands in WLFZ are generally used to cultivate maize, soybean, wood, and reed. A lot of fertilizers are needed for a highyield maize. $\left(\mathrm{NH}_{4}\right)_{2} \mathrm{HPO}_{4}$ is used as a common fertilizer with a dosage of $750 \mathrm{~kg} \mathrm{ha}^{-1}$ for maize and about $150 \mathrm{~kg}$ $\mathrm{ha}^{-1}$ for soybean growth. The organic fertilizer for wood land is limited, while no fertilizer is applied in reed land. Based on the difference in type and dosage of fertilizer for different plants, four different types of land, i.e., maize, soybean, wood, and reed land, were selected in this study.

Soil samples (about $1000 \mathrm{~g}$ for wet weight) were collected from surface soils $(0-10 \mathrm{~cm})$ separately at three sites for each type of land (reed, wood, maize, and soybean) in November 2013. Samples from the same type of land were homogenized prior to tests. At below soil analysis, all samples were analyzed in triplicate, and the results were expressed as mean and standard deviation.

\section{Soil Analysis}

All samples were collected in sealed plastic bags, frozen, and then transferred to the laboratory of Weishan Station, where soil samples were freeze-dried, ground in an agate mortar, and sieved with a standard $2 \mathrm{~mm}$ sieve for further studies. The grain size distribution of sediment samples was analyzed using a Mastersizer 2000 Laser Size Analyzer (Malvern Co., UK), and was classified into clay $(0.02-4.0 \mu \mathrm{m})$, silt $(4-63 \mu \mathrm{m})$, and sand fractions $(63-2,000 \mu \mathrm{m})[25]$. The total contents of major elements as $\mathrm{Fe}$ and $\mathrm{Al}$ were measured by ICP-AES PS-950 after digestion. Organic matter (OM) content was measured as weight loss after ignition at $550^{\circ} \mathrm{C}$ for $6 \mathrm{~h}$ [26]. The soil $\mathrm{pH}$ value was measured in saturated paste using a glass electrode, and cation exchange capacity (CEC) using $\mathrm{NaOAc}$ method [27].

\section{Phosphorus Fractions and Analysis}

A harmonized scheme (SMT protocol) to determine the extractable phosphorus contents in freshwater sediments has been harmonized through interlaboratory studies in the frame of the Standards Measurements and Testing Program of the European Commission [28]. A homogeneous and stable sediment reference material was prepared based on this SMT protocol. The SMT protocol, together with the reference material, is a useful tool in the field of water management. It has been developed based on the comparison of existing schemes and inter-laboratory studies. This operationally defined scheme consists of five steps i.e., extraction of $\mathrm{NaOH}$-extractable $\mathrm{P}$ ( $\mathrm{P}$ bound to $\mathrm{Al}, \mathrm{Fe}$ and $\mathrm{Mn}$ oxides and hydroxides), $\mathrm{HCl}$-extractable $\mathrm{P}$ ( $\mathrm{P}$ associated with $\mathrm{Ca}$ ), organic $\mathrm{P}(\mathrm{OP})$, inorganic $\mathrm{P}$ (IP), and concentrated $\mathrm{HCl}$-extractable $\mathrm{P}$ (total $\mathrm{P}, \mathrm{TP}$ ).

For the first step, $0.2 \mathrm{~g}$ soil was placed into a 50 $\mathrm{mL}$ acid-washed screw cap centrifuge tube and $20 \mathrm{~mL}$ $1 \mathrm{~mol} \mathrm{~L}^{-1} \mathrm{NaOH}$ solution was added for $\mathrm{NaOH}-\mathrm{P}$ extraction. In the second step the residue of the first step

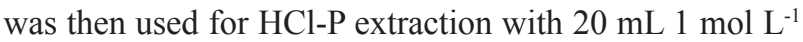
$\mathrm{HCl}$ solution. The third step saw $0.2 \mathrm{~g}$ soil extracted with $20 \mathrm{~mL} 1 \mathrm{~mol} \mathrm{~L}^{-1} \mathrm{HCl}$ solution for IP, and the residue of this step was extracted with $20 \mathrm{~mL} 1 \mathrm{~mol} \mathrm{~L}^{-1} \mathrm{HCl}$ solution after ignition $\left(450^{\circ} \mathrm{C}\right)$ for $\mathrm{OP}$ (fourth step). In the fifth step $0.2 \mathrm{~g}$ soil was extracted with $20 \mathrm{~mL} 3.5 \mathrm{~mol} \mathrm{~L}^{-1} \mathrm{HCl}$ solution after ignition $\left(450^{\circ} \mathrm{C}\right)$ for TP [28].

The extract solution was centrifuged at 5,000 rpm for $15 \mathrm{~min}$ and then filtered through a $1.2 \mu \mathrm{m} \mathrm{GF} / \mathrm{C}$ filter membrane. The P concentration (as the form of phosphate) in solution was analyzed using the molybdenum-blue method [29]. The P concentration in each P fraction was calculated based on phosphate concentration, solution volume, and soil sample weight.

\section{Phosphate Adsorption Isotherm Experiments}

One-gram air-dried soil samples were weighed in an acid-washed conical flask $(250 \mathrm{ml})$, and $200 \mathrm{ml}$ phosphorus standard solutions (anhydrous $\mathrm{KH}_{2} \mathrm{PO}_{4}$ ) of various concentrations $(0,0.02,0.05,0.1,0.2,0.5$, and $1.0 \mathrm{mg} \mathrm{L}^{-1}$ ) were added. Two drops of $0.1 \%$ chloroform were added to inhibit bacterial activities. The $\mathrm{pH}$ values of the solutions were adjusted to $7.0-8.0$ by adding $0.01 \mathrm{~mol}$ $\mathrm{L}^{-1}$ and $0.01 \mathrm{~mol} \mathrm{~L}^{-1}$, which were similar to the actual $\mathrm{pH}$ in the Lake. The flasks were capped and placed at $20 \pm 1^{\circ} \mathrm{C}$ in an orbital shaker at $250 \mathrm{rpm}$ for $24 \mathrm{~h}$ to ensure equilibrium. After equilibrium and centrifuging $(5,000 \mathrm{rpm}$ for $15 \mathrm{~min}$ ), the suspension was filtered through a $1.2 \mu \mathrm{m}$ $\mathrm{GF} / \mathrm{C}$ membrane filter and the phosphate concentration was measured by the molybdenum-blue method [29]. The phosphate adsorbed on the soil samples was calculated 
Table 1. Physical and chemical characteristics of four soils.

\begin{tabular}{|c|c|c|c|c|c|c|c|c|c|c|}
\hline $\begin{array}{c}\text { Land } \\
\text { uses }\end{array}$ & $\begin{array}{c}\mathrm{OM} \\
(\%)\end{array}$ & $\begin{array}{c}\mathrm{TP} \\
\left(\mathrm{mg} \mathrm{kg}^{-1}\right)\end{array}$ & $\begin{array}{c}\mathrm{TN} \\
\left(\mathrm{mg} \mathrm{kg}^{-1}\right)\end{array}$ & $\begin{array}{c}\mathrm{Al} \\
\left(\mathrm{mg} \mathrm{kg}^{-1}\right)\end{array}$ & $\begin{array}{c}\mathrm{Fe} \\
\left(\mathrm{mg} \mathrm{g}^{-1}\right)\end{array}$ & $\mathrm{pH}$ & $\begin{array}{c}\mathrm{CEC} \\
\left(\mathrm{mol} \mathrm{kg}^{-1}\right)\end{array}$ & $\begin{array}{c}\text { Clay } \\
(\%)\end{array}$ & $\begin{array}{c}\text { Slit } \\
(\%)\end{array}$ & $\begin{array}{c}\text { Sand } \\
(\%)\end{array}$ \\
\hline reed & $8.33( \pm 0.21)$ & $442.8( \pm 6.2)$ & $1316( \pm 21)$ & $213.0( \pm 9.2)$ & $161.5( \pm 10.2)$ & 8.17 & $56.7( \pm 4.2)$ & $3.80( \pm 3.2)$ & $24.3( \pm 5.5)$ & $68.1( \pm 8.5)$ \\
\hline wood & $10.44( \pm 0.30)$ & $584.2( \pm 8.1)$ & $1652( \pm 15)$ & $279.9( \pm 7.3)$ & $206.1( \pm 22.2)$ & 8.09 & $99.5( \pm 6.5)$ & $3.8( \pm 3.5)$ & $31.0( \pm 5.8)$ & $61.3( \pm 8.2)$ \\
\hline maize & $11.49( \pm 0.25)$ & $1164.8( \pm 9.2)$ & $1988( \pm 24)$ & $330.0( \pm 5.2)$ & $221.7( \pm 15.6)$ & 8.04 & $87.3( \pm 6.6)$ & $4.8( \pm 3.0)$ & $32.1( \pm 6.6)$ & $58.3( \pm 9.0)$ \\
\hline soybean & $8.22( \pm 0.23)$ & $856.7( \pm 4.2)$ & $1428( \pm 18)$ & $307.1( \pm 9.1)$ & $236.5( \pm 14.8)$ & 8.10 & $122.4( \pm 7.3)$ & $1.4( \pm 2.2)$ & $19.6( \pm 6.4)$ & $77.6( \pm 7.8)$ \\
\hline
\end{tabular}

based on the difference between the initial and equilibrium phosphate concentrations.

The phosphate adsorption isotherm was fitted according to Eq. 1. [30]

$$
\mathrm{Q}=\mathrm{mC}_{\mathrm{eq}}-\omega_{\mathrm{NAP}}
$$

...where $\mathrm{C}_{\mathrm{eq}}$ is the phosphate concentration in solution after a $24 \mathrm{~h}$ equilibration period $\left(\mathrm{mg} \mathrm{L}^{-1}\right), \mathrm{Q}$ is the amount of phosphate adsorbed by the solid phase $\left(\mathrm{mg} \mathrm{kg}^{-1}\right), \mathrm{m}$ is the slope (which is a measure of the phosphate sorption efficiency of the sediments), and $\omega_{\mathrm{NAP}}$ is the content of native adsorbed phosphorus (NAP) $\left(\mathrm{mg} \mathrm{kg}^{-1}\right)$.

Phosphorus adsorption-desorption equilibrium concentration or zero equilibrium phosphorus concentration $\left(\mathrm{C}_{\mathrm{EPC}}\right)$ is an important parameter that provides useful information whether a given soil releases or adsorbs phosphate. If $\mathrm{C}_{\mathrm{eq}}<\mathrm{C}_{\mathrm{EPC}}, \mathrm{NAP}$ will be released from the soil to water. Conversely, if $\mathrm{C}_{\mathrm{eq}}>\mathrm{C}_{\mathrm{EPC}}$, phosphate in water will be adsorbed by soil. When $\mathrm{C}_{\mathrm{eq}}=\mathrm{C}_{\mathrm{EPC}}$, the adsorption and desorption reached an equilibrium state within the system $[26,30]$.

\section{Soil Submerged Experiment}

A soil submerged experiment was performed to determine the phosphorus adsorption/desorption potential for four different soil samples. Soil samples (200 g) were put into four glass pipes with a diameter of $9 \mathrm{~cm}$ and a length of $80 \mathrm{~cm}$, and the bottom of the pipes were sealed with rubber stoppers. In each pipe, $2 \mathrm{~L}$ of water collected from Nansi Lake $\left(0.038 \mathrm{mg} \mathrm{PO}_{4}^{3-}-\mathrm{P} \mathrm{L}^{-1}\right)$ was added by siphon. Subsequently, overlying water samples (100 ml) were collected from each pipe at $1,3,7,15$, and $28 \mathrm{~d}$, filtered through a $1.2 \mu \mathrm{m} \mathrm{GF} / \mathrm{C}$ filter membrane, and then used for phosphate analysis.

\section{Results and Discussion}

\section{Soil Characteristics}

The physical and chemical characteristics of the soils are shown in Table 1. The sequence of TP contents in the soil samples from different lands are maize $>$ soybean $>$ wood $>$ reed, while $\mathrm{TN}$ contents are maize $>$ wood $>$ soybean $>$ reed.
The contents of TP and TN in the soils from maize land were $1,164.8 \mathrm{mg} \mathrm{kg}^{-1}$ and $2016 \mathrm{mg} \mathrm{kg}^{-1}$, respectively, which were the highest among all samples. The contents from reed land were the lowest, at $442.8 \mathrm{mg} \mathrm{TP} \mathrm{kg}^{-1}$ and $1316 \mathrm{mg} \mathrm{TN} \mathrm{kg}{ }^{-1}$, respectively. This indicated that the contamination levels of the soils were determined by the types of dosage of fertilizers applied. The highest levels were the samples from maize due to excessive fertilizer accumulated in the soils. In addition, the phosphorus concentration in soils with phosphorus fertilizers increased with cultivation time [19, 20, 31]. Shi Y. et al. suggested that total $\mathrm{P}$ declined under the corn-soybean rotation, and the combined no-tillage and P fertilization enhanced soil $\mathrm{Pi}$ fractions, thereby improving soil $\mathrm{P}$ supplying capacity and $P$ balance [32]. Less fertilizer is applied in soybean land, and a small quantity of organic fertilizer is applied in woodland. Therefore, TP and TN contents in these two soils were lower than the one in maize land separately. As the soil phosphorus is continuously removed by the harvest of reed, which uptakes phosphorus from the soil, the phosphorus in reed land decreases gradually.

The grain size distribution of the soil particles of the samples was classified into clay, silt, and sand fractions (Table 1). Sand was the major fraction of all soils, accounting for $58.3-77.6 \%$ of the total particles. Clay was the minor fraction, accounting for $1.4-4.8 \%$ of the total. Our observation is different from what was previously reported by $\mathrm{An}$ and $\mathrm{Li}$ about sediment samples of Nansi Lake silt fraction being the major fraction [30]. The proportions of clay and silt grains of the soils from WLFZ were smaller than those in the sediments in Nansi

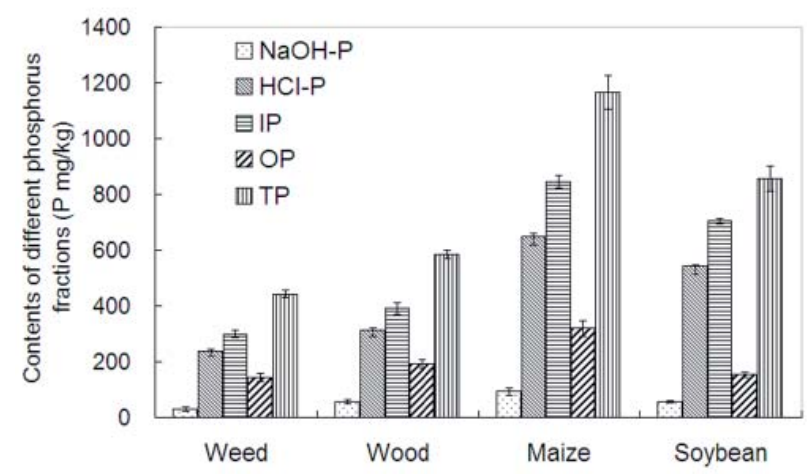

Fig. 2. Distribution of soil phosphorus fractions in the Nansi Lake WLFZ. 
Table 2. The proportions of $\mathrm{P}$ fractions to TP.

\begin{tabular}{|c|c|c|c|c|}
\hline Land uses & $\begin{array}{c}\mathrm{NaOH}-\mathrm{P} \\
\%\end{array}$ & $\begin{array}{c}\text { HCl-P } \\
\%\end{array}$ & $\begin{array}{c}\text { IP } \\
\%\end{array}$ & $\begin{array}{c}\text { OP } \\
\%\end{array}$ \\
\hline reed & 6.77 & 53.68 & 67.74 & 32.26 \\
\hline wood & 9.63 & 53.48 & 66.90 & 33.10 \\
\hline maize & 7.95 & 55.78 & 72.56 & 27.44 \\
\hline soybean & 6.80 & 63.57 & 82.15 & 17.85 \\
\hline
\end{tabular}

Lake. Due to the differences in specific surface areas, the adsorption and ion-exchange capability for phosphate was different, and the finer grains have greater adsorption capacity because of the higher specific surface area. The soils in WLFZ with lower portion of clay and silt grains have less capacity to adsorb phosphorus. Therefore, phosphorus would be released easily from soils in WLFZ than the sediments in Nansi Lake.

The CEC values in the soil samples were different. The reed land soil had the lowest CEC values of $56.7 \mathrm{~mol} \mathrm{~kg}^{-1}$, and soybean land soil had the highest CEC value of $122.4 \mathrm{~mol} \mathrm{~kg}^{-1}$ (Table 1). The CEC values did not show correlation with phosphorus content. The $\mathrm{pH}$ values of the samples indicate that these soils are slightly alkaline, varying from 8.04 to 8.17 . The contents of $\mathrm{Al}$ and Fe showed slight differences in the different soils. The reed land samples contained less $\mathrm{Fe}$ and $\mathrm{Al}$ than the other samples (Table 1).

\section{Phosphorus Fractions}

The contents of different phosphorus fractions in the soils from four types of land are shown in Fig. 2. The contents of TP and phosphorus fractions varied greatly. TP contents in the soils ranged from 442.8 to $1,164.8 \mathrm{mg} \mathrm{kg}^{-1}$ and the average content was $762.1 \mathrm{mg} \mathrm{kg}^{-1}$. IP contents in all the soils varied from 299.9 to $845.2 \mathrm{mg} \mathrm{kg}^{-1}$, accounting for more than $65 \%$ of TP, and the OP contents ranged from 142.9 to $319.6 \mathrm{mg} \mathrm{kg}^{-1}$. HCl-P contents ranged from 237.7 to $649.7 \mathrm{mg} \mathrm{kg}^{-1}$, accounting for more than $50 \%$ of TP, and $\mathrm{NaOH}-\mathrm{P}$ from 29.9 to $92.6 \mathrm{mg} \mathrm{kg}^{-1}$, lower than $10 \%$ of TP.

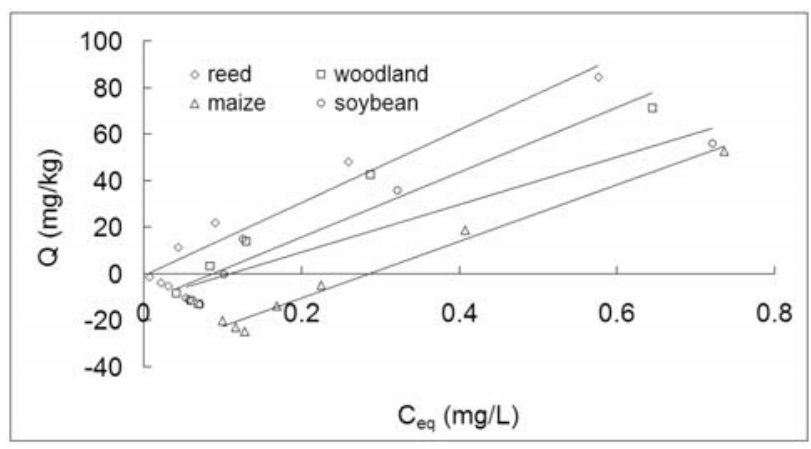

Fig. 3. Phosphate adsorption isotherms of the soils. (Reed, wood, maize, and soybean represent land with different types of land use, respectively.)
The proportions of IP in TP were higher in maize land and soybean land than those in reed land and woodland (Table 2). Guo et al. suggested that phosphorus accumulation in soils increased due to the long-term continuous application of phosphorus fertilizers, and the phosphorus accumulated in the soils were mainly transformed into Ca-P (HCl-P) [33]. The result was agreement with the Li Y et al. report, with comparison of the no-fertilizer addition, the long-term single fertilization (inorganic nitrogen and $\mathrm{P}$ fertilizer) significantly increased the accumulation of $\mathrm{NaHCO}_{3}^{-}, \mathrm{NaOH}-$, and $\mathrm{HCl}$-extractable $\mathrm{P}-\mathrm{i}$ (residual P) fractions, accounting for two- to three-fold, while the straw incorporation and green manure as fertilizer increased the accumulation of IP, accounting for $12-60 \%$ [20]. Therefore, woodland had the highest proportion of OP, probably due to the lower application of inorganic fertilizer or the application of organic fertilizer [34]. Previous studies indicated that large surplus phosphorus inputs were associated with manure application, which could influence the distribution of phosphorus among organic and inorganic forms [13, 35]. Yin Y. concluded that applying organic fertilizer can increase the content of the phosphorus fractions of paddy soil. While with microorganisms present, Al-P and $\mathrm{Ca}-\mathrm{P}$ can be transformed into moderately labile organic phosphorus and moderately resistant organic phosphorus, and OP can be transformed into highly resistant organic phosphorus [36]. Therefore, the phosphorus fractions in soil under different fertilizers were changeable with the environmental conditions.

The most labile fraction of phosphorus found in soils is undoubtedly $\mathrm{NaOH}-\mathrm{P}$, which is easily released from soil to water. $\mathrm{NaOH}-\mathrm{P}$ of maize land is three times that of reed land. NaOH-P concentration of soybean and wood land samples is two times that of reed land. The reason was probably that the lands of soybean, maize, and wood were all cultivated land, to which was added more inorganic fertilizer [19, 20, 37]. This suggests that soils in maize, soybean, and woodland have higher environmental concern than soils in reed land when this zone would be submerged.

\section{Phosphate Adsorption Isotherm}

The phosphate adsorption isotherms are shown in Fig. 3 and the linearly fitted results of phosphate adsorption isotherms are shown in Table 3. The soil $\mathrm{C}_{\mathrm{EPC}}$ in reed land,

Table 3. The linearly fitted results of phosphate adsorption isotherms.

\begin{tabular}{|c|c|c|c|c|}
\hline sites & $\begin{array}{c}\mathrm{m} \\
\left(1 \mathrm{~kg}^{-1}\right)\end{array}$ & $\begin{array}{c}\omega_{\mathrm{NAP}} \\
\left(\mathrm{mg} \mathrm{kg}^{-1}\right)\end{array}$ & $\begin{array}{c}\mathrm{C}_{\mathrm{EPC}} \\
\left(\mathrm{mg} \mathrm{L}^{-1}\right)\end{array}$ & $\mathrm{R}^{2}$ \\
\hline reed & 156.37 & 0.90 & 0.006 & 0.95 \\
\hline wood & 139.32 & 12.39 & 0.089 & 0.92 \\
\hline maize & 121.99 & 35.03 & 0.287 & 0.99 \\
\hline soybean & 101.96 & 11.24 & 0.110 & 0.87 \\
\hline
\end{tabular}


which did not receive fertilizer containing phosphorus, was only $0.006 \mathrm{mg} \mathrm{L}^{-1}$, while those from the maize, soybean, and woodland were $0.287,0.11$, and $0.089 \mathrm{mg}$ $\mathrm{L}^{-1}$, respectively. Maize, soybean, and woodland had higher $\mathrm{C}_{\mathrm{EPC}}$ than reed land, probably due to long-term fertilization. Shafqat and Pierzynski used the Freundlich model $\left(A=K C^{1 / n}\right)$ to describe phosphorus adsorption to sediments. In the model, $A$ represents the amount of $\mathrm{P}$ sorbed by the solid phase $\left(\mathrm{mg} \mathrm{kg}^{-1}\right), \mathrm{C}$ is the solution $\mathrm{P}$ concentration $\left(\mathrm{mg} \mathrm{L}^{-1}\right)$ after equilibration, and $\mathrm{K}$ and $1 / \mathrm{n}$ are the Freundlich constants. The Freundlich $\mathrm{K}$ refers to the ratio of $\mathrm{P}$ adsorbed to $\mathrm{P}$ in the soil solution, while $1 / \mathrm{n}$ describes the non-linearity of the adsorption curve. Shafqat and Pierzynski reported that much higher Freundlich K and smaller $1 / \mathrm{n}$ values were observed for the P-deficient soil, which means that the higher the $\mathrm{K}$, the more $\mathrm{P}$ adsorbed to sediments, or the stronger the adsorb potential to the sediments; therefore the $\mathrm{P}$ was difficult to release to the overlaying water. The result is consistence in our results, and the weed land with $\mathrm{P}$ deficient soil has lower $\mathrm{C}_{\mathrm{EPC}}$ with lower potential for P release [38]. Some of the previous adsorped phosphorus occupied the adsorption sites and blocked further reaction, thus the phosphorus sorption capacity in fertilize in fertilized soils decreased [33].

According to government regulations, after the SNWD project is completed, the water quality of Nansi Lake should be better than grade III of the China surface water quality standard (GB3838-2002), which requires TP concentration below $0.05 \mathrm{mg} / \mathrm{L}$. The TP content of the overlying water after diversion is higher than $\mathrm{C}_{\mathrm{EPC}}$ at the sample sites of reed land, so the soils in reed land will not release phosphorus and cause water quality concern. But the soils in woodland, maize land, and soybean land with $\mathrm{C}_{\mathrm{EPC}}$ higher than TP of the overlying water $\left(<0.05 \mathrm{mg} \mathrm{L}^{-1}\right)$ will tend to release phosphorus to overlying water, which has a chance to threaten water quality. Therefore, the inherent phosphorus of the soils of these types of farmland could be of concern to water quality.

In the isotherm equation, the term of $\omega_{\mathrm{NAP}}$ can be considered to be phosphorus adsorbing on the soil surface mainly by physical effects, and is easily desorbed from the

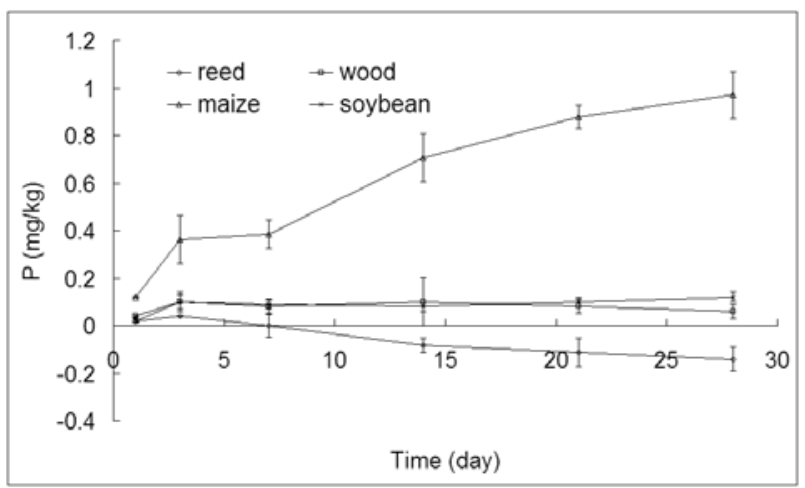

Fig. 4. Soil phosphorus releasing under submerged conditions. (Reed, wood, maize, and soybean represent land with different types of land use, respectively.) surface into the water [30]. Soils in maize land, soybean land, and woodland had much higher $\omega_{\mathrm{NAP}}$ than that in reed land. This indicates that more soil phosphorus may be released from maize, soybean, and woodland and cause higher environmental threats than reed land in the future.

\section{Soil Submerged Experiment}

The phosphorus release phenomena from soil under submerged conditions over 28 days are illustrated in Fig. 4. This indicates that the soil sample from the reed land adsorbed phosphorus from the overlying water and the TP concentration decreased gradually with time. Therefore, the quantity of phosphorus released from reed soil $\left(\mathrm{Q}_{\mathrm{PR}}\right)$ was $-0.14 \mathrm{mg} / \mathrm{kg}$. Soil phosphorus was released from woodland and soybean land samples under submerged conditions, but the $\mathrm{Q}_{\mathrm{PR}}$ from both soils were much lower (wood $0.06 \mathrm{mg} \mathrm{kg}^{-1}$; soybean $0.12 \mathrm{mg} \mathrm{kg}^{-1}$ ). Soil phosphorus from maize land was consistently released throughout the 28-day period, and the $\mathrm{Q}_{\mathrm{PR}}$ was at least $0.97 \mathrm{mg} \mathrm{kg}^{-1}$. If a longer test period were applied, a higher $\mathrm{Q}_{\mathrm{PR}}$ would be expected.

Based on the above observations, the soil in reed land adsorbs phosphorus from overlying water, but other soils may release phosphorus into the overlying water at different levels when WLFZ is submerged. Soils in maize land, soybean land, and woodland tend to release phosphorus to overlying water and will threaten the water quality to some extent after SNWD (East route) is completed at the beginning. It may take months or longer to flush out the phosphorus-rich soils until no phosphorus is released.

Reed wetland has been widely used for water purification in many projects $[39,40]$ in which the phosphorus in soil absorbed by reed can be easily removed by harvesting reed plants. To maintain high water quality, the land in WLFZ should not be utilized for wood, soybean, and maize, and should be switched to plant reed gradually in order to reduce phosphorus loading. The strategy of returning the farmland into the lake shore with reed can ensure not only the water quality of Nansi Lake, but also preserve the lake's beautiful landscape.

\section{Conclusions}

The soils in WLFZ near Nansi Lake were characterized for phosphorus release concern in the SNWD project. The $\mathrm{C}_{\mathrm{EPC}}$ and the quantities of phosphorus released $\left(\mathrm{Q}_{\mathrm{PR}}\right)$ in the submerged experiment indicate that soil in reed land adsorbed phosphorus from overlying water. However, soils in maize, soybean, and woodland released phosphorus into the overlying water at different levels. Phosphorus release from the soils in WLFZ could threaten water quality in the future. Therefore, technical approaches should be taken to reduce the phosphorus release from the lands in WLFZ before the SNWD project is put in use for transporting water from the Yangtze. At present, in order to reduce phosphorus loading, the application of 
phosphorus fertilizers to the land in the WLFZ should be reduced, and the land uses of wood, soybean, and maize should be changed to reed land gradually, which also can purify the lake water and bring about economic benefits.

\section{Acknowledgements}

This research was financially supported by the Foundation of Environmental Protection for Lake and River's Sediments (No. [2012] 67, No. [2015] 302), and Natural Science Foundation of Shandong Province for providing the financial support (No. BS2013HZ028).

\section{References}

1. LIN J.J., FU C., ZHANG X.D., XIE K., YU Z.G. Heavy Metal Contamination in the Water-Level Fluctuating Zone of the Yangtze River within Wanzhou Section, China. Biol. Trace Elem. Res., 145 (2), 268, 2012.

2. ZHANG B., FANG F., GUO J.S., LI Z., FU C. Distribution Characteristics and Evaluation of Soil Som, Tn, Tp in the Water-Level-Fluctuating Zone of Three Gorges Reservoir. Fresenius Environ. Bull., 21 (12A), 3779, 2012.

3. CHEN F.Q., XIE Z.Q. Ecophysiological Response of Two Hrebaceous Species to Flooding Implication for Ecological Restoration of Vegetation on water level fluctuating zone. 2011 International Conference on Electronics, Communications and Control (Icecc), 4260, 2011.

4. CHEN F.Q., WU J.T., XU W.N.A., LIU D.F. Ecological Experiment of Vegetation Restoration on the Water-levelfluctuating Zone in Geheyan Reservoir, Qingjiang River. Proceedings of the 4th International Yellow River Forum on Ecological Civilization and River Ethics, Vol Ii, 93, 2010 [in Chinese].

5. RIIS T., HAWES I. Relationships between water level fluctuations and vegetation diversity in shallow water of New Zealand lakes. Aquat. Bot., 74 (2), 133, 2002.

6. LAWNICZAK A.E., ZBIERSKA J., CHOINSKI A., SZCZEPANIAK W. Response of emergent macrophytes to hydrological changes in a shallow lake, with special reference to nutrient cycling. Hydrobiologia, 656 (1), 243, 2010.

7. KEDDY P.A., REZNICEK A.A. Great Lakes Vegetation Dynamics: The Role of Fluctuating Water Levels and Buried Seeds. J. Gt. Lakes Res., 12, 25, 1986.

8. LIN J.J., LIU D., FU C., YU Z.G. Ecological Risk Caused in Soil by Heavy Metals in the water level fluctuating zone of a Yangtze River Tributary. Environmental Engineering and Management Journal, 13 (4), 923, 2014 [in Chinese].

9. FANG F., YANG Y., GUO J.S., ZHOU H., FU C., LI Z. Three-dimensional fluorescence spectral characterization of soil dissolved organic matters in the fluctuating water-level zone of Kai County, Three Gorges Reservoir. Frontiers of Environmental Science \& Engineering in China, 5 (3), 426, 2011.

10. SASIKALA S., TANAKA N., WAH H.S.Y.W., JINADASA K.B.S.N. Effects of water level fluctuation on radial oxygen loss, root porosity, and nitrogen removal in subsurface vertical flow wetland mesocosms. Ecological Engineering, 35 (3), 410, 2009.

11. SCHWARTZ R.C., DAO T.H., BELL J.M. Manure and Mineral Fertilizer Effects on Seasonal Dynamics of Bioactive Soil Phosphorus Fractions. Agron. J., 103 (6), 1724, 2011.
12. DESIGNING GROUP FOR WATER POLLUTION PREVENTION AND CONTROL PLANNING OF SOUTH TO NORTH WATER DIVERSION PROJECT IN SHANDONG SECTION. Water pollution prevention and control planning for South to North Water Diversion project in Shandong section. Jinan, 2002 [in Chinese].

13. HOODA P.S., TRUESDALE V.W., EDWARDS A.C., WITHERS P.J.A., AITKEN M.N., MILLER A., RENDELL A.R. Manuring and fertilization effects on phosphorus accumulation in soils and potential environmental implications. Advances in Environmental Research, 5 (1), 13, 2001.

14. MAZURZ., MAZUR T. Influence of Long-Term Fertilization on Phosphorus, Potassium, Magnesium, and Sulfur Content in Soil. Pol. J. Environ. Stud., 24 (1), 185, 2015.

15. PIOTROWSKA-DLUGOSZ A., WILCZEWSKI E. Soil Phosphatase Activity and Phosphorus Content as Influenced by Catch Crops Cultivated as Green Manure. Pol. J. Environ. Stud., 23 (1), 157, 2014.

16. POTE D.H., DANIEL T.C., SHARPLEY A.N., MOORE P.A., EDWARDS D.R., NICHOLS D.J. Relating extractable soil phosphorus to phosphorus losses in runoff. Soil Sci. Soc. Am. J., 60 (3), 855, 1996.

17. SHARPLEY A.N. Dependence of Runoff Phosphorus on Extractable Soil-Phosphorus. J. Environ. Qual., 24 (5), 920, 1995.

18. ZHOU Q.X., ZHU Y.M. Potential pollution and recommended critical levels of phosphorus in paddy soils of the southern Lake Tai area, China. Geoderma, 115 (1-2), 45, 2003.

19. SHI Y.C., ZIADI N., MESSIGA A.J., LALANDE R., HU Z.Y. Soil Phosphorus Fractions Change in Winter in a CornSoybean Rotation with Tillage and Phosphorus Fertilization. Pedosphere, 25 (1), 1, 2015.

20. LI Y.Y., YANG R., GAO R., WEI H.A., CHEN A.L., LI Y. Effects of long-term phosphorus fertilization and straw incorporation on phosphorus fractions in subtropical paddy soil. Journal of Integrative Agriculture, 14 (2), 365, 2015.

21. YANG K., ZHU J.J., GU J.C., YU L.Z., WANG Z.Q. Changes in soil phosphorus fractions after 9 years of continuous nitrogen addition in a Larix gmelinii plantation. Ann. For. Sci., 72 (4), 435, 2015.

22. YANG W.J., HAO F.H., CHENG H.G., LIN C.Y., OUYANG W. Phosphorus Fractions and Availability in an Albic Bleached Meadow Soil. Agron. J., 105 (5), 1451, 2013.

23. SCHMITT D.E., GATIBONI L.C., GIROTTO E., LORENSINI F., MELO G.W.B., BRUNETTO G. Phosphorus fractions in the vineyard soil of the Serra Gaucha of Rio Grande do Sul, Brazil. Revista Brasileira De Engenharia Agricola E Ambiental, 18 (2), 134, 2014.

24. ZHANG B., FANG F., YANG Y., GUO J.S., LI Z., FU C. Fluorescent Characteristics of Dissolved Organic Matters in Soil at water level fluctuating zone (WLFZ) in Kaixian of Three Gorges Reservoir and Their Spacial Distributions. 2012 World Automation Congress (Wac), 2012.

25. JIN X.C., WANG S.R., PANG Y., ZHAO H.C., ZHOU X.N. The adsorption of phosphate on different trophic lake sediments. Colloids and Surfaces a-Physicochemical and Engineering Aspects, 254 (1-3), 241, 2005.

26. ZHOU A.M., TANG H.X., WANG D.S. Phosphorus adsorption on natural sediments: Modeling and effects of $\mathrm{pH}$ and sediment composition. Water Res., 39 (7), 1245, 2005.

27. RHOADS J.W. Cation exchange capacity. In: Page, A.C. (Ed.), Methods of Soil Analysis. Part 2. Am. Soc. Agron, Madison, 149, 1986.

28. RUBAN V., LOPEZ-SANCHEZ J.F., PARDO P., RAURET G., MUNTAU H., QUEVAUVILLER P. Harmonized protocol and certified reference material for the determination of 
extractable contents of phosphorus in freshwater sediments A synthesis of recent works. Fresenius Journal of Analytical Chemistry, 370 (2-3), 224, 2001.

29. 2MURPHY J., RILEY J.P. A modified single solution method for the determination of phosphate in natural waters. Anal. Chim. Acta, 27 (31-36), 1962.

30. AN W.C., LI X.M. Phosphate adsorption characteristics at the sediment-water interface and phosphorus fractions in Nansi Lake, China, and its main inflow rivers. Environ. Monit. Assess., 148 (1-4), 173, 2009.

31. MA Y.B., LI J.M., LI X.Y., TANG X., LIANG Y.C., HUANG, S.M., WANG B.R., LIU H., YANG X.Y. Phosphorus accumulation and depletion in soils in wheat-maize cropping systems: Modeling and validation. Field Crops Res., 110 (3), 207, 2009.

32. SHI Y.C., ZIADI N., MESSIGA A.J., LALANDE R., HU Z.Y. Changes in Soil Phosphorus Fractions for a LongTerm Corn-Soybean Rotation with Tillage and Phosphorus Fertilization. Soil Sci. Soc. Am. J., 77 (4), 1402, 2013.

33. GUO S.L., DANG T.H., HAO M.D. Phosphorus changes and sorption characteristics in a calcareous soil under longterm fertilization. Pedosphere, 18 (2), 248, 2008.

34. COUTO R.D., DOS SANTOS M., COMIN J.J., MARTINI L.C.P., GATIBONI L.C., MARTINS S.R., BELLI P., BRUNETTO G. Environmental Vulnerability and Phosphorus Fractions of Areas with Pig Slurry Applied to the Soil. J. Environ. Qual., 44 (1), 162, 2015.

35. BRUNETTO G., LORENSINI F., CERETTA C.A., GATIBONI L.C., TRENTIN G., GIROTTO E., MIOTTO A., LOURENZI C.R., DE MELO G.W. Soil Phosphorus Fractions in a Sandy Typic Hapludaft as Affected by Phosphorus Fertilization and Grapevine Cultivation Period. Commun. Soil Sci. Plant Anal., 44 (13), 1937, 2013.

36. YIN Y., LIANG C.H. Transformation of phosphorus fractions in paddy soil amended with pig manure. Journal of Soil Science and Plant Nutrition, 13 (4), 809, 2013.

37. BRAOS L.B., DA CRUZ M.C.P., FERREIRA M.E., KUHNEN F. Organic Phosphorus Fractions in Soil Fertilized with Cattle Manure. Revista Brasileira De Ciencia Do Solo, 39 (1), 140, 2015

38. SHAFQAT M.N., PIERZYNSKI G.M. The Freundlich adsorption isotherm constants and prediction of phosphorus bioavailability as affected by different phosphorus sources in two Kansas soils. Chemosphere, 99, 72, 2014.

39. DECAMP O., WARREN A. Bacterivory in ciliates isolated from constructed wetlands (reed beds) used for wastewater treatment. Water Res., 32 (7), 1989, 1998.

40. MADDISON M., SOOSAAR K., MAURING T., MANDER $\mathrm{U}$. The biomass and nutrient and heavy metal content of cattails and reeds in wastewater treatment wetlands for the production of construction material in Estonia. Desalination, 246 (1-3), 120, 2009. 